\title{
La promesa unilateral y la responsabilidad civil
}

\author{
Henry Huanco Piscoche \\ Abogado por la Universidad Nacional Mayor de San Marcos. \\ Máster en Asesoría y Consultoría Inmobiliaria por la Universidad de Barcelona. \\ Profesor de Derecho Civil y Arbitraje en la Universidad Nacional Mayor de San Marcos. \\ Profesor de Derecho Civil y Arbitraje en la Universidad Peruana de Ciencias Aplicadas. \\ Profesor de Derecho Civil y Arbitraje en la en la Universidad de Piura. \\ Miembro del Grupo de Trabajo encargado de revisar la Ley 27157 y su Reglamento. \\ Secretario Técnico y Asesor del Grupo de Trabajo que se encargó de proponer mejoras al Código Civil. \\ Fundador de la Asociación Peruana de Derecho Inmobiliario.
}

\section{SUMARIO:}

I. Antecedentes históricos de la promesa unilateral.

1. Derecho romano.

1.1. La pollicitatio.

1.2. El votum.

2. Derecho canónico: el iuramentum promisorio.

3. Derecho alemán: el auslobung.

4. Apostilla.

II. La promesa unilateral en la legislación comparada.

1. El Code Civil francés.

2. El BGB alemán.

3. EI Codice Civile italiano.

III. Breve excursus sobre la promesa unilateral en la legislación peruana.
1. Código Civil de 1852.
2. Código Civil de 1936.
3. Código Civil de 1984.

IV. La promesa unilateral en el Código Civil peruano.

1. El artículo 1956.

2. Supuestos en los que la promesa unilateral es obligatoria.

3. Casos previstos por la ley.

4. Casos en que existe acuerdo previo entre las partes.

5. ¿Cuándo una declaración unilateral constituye una promesa unilateral?

6. La promesa de pública recompensa y la promesa como premio de un concurso.

V. La responsabilidad civil en la promesa unilateral.

1. Consideraciones generales.

1.1. Si la promesa no tiene plazo de validez determinado.

1.2. Si la promesa tiene plazo de validez determinado.

1.3. Momento de la revocación y "justo motivo".

1.4. Indemnización a quienes confiaron en la vigencia de la promesa.

1.5. Daños sufridos por el promisario mayores al monto de la recompensa.

1.6. Invalidez de la revocación.

1.7. Renuncia al derecho de revocación. 


\title{
RESUMEN:
}

La promesa unilateral es un instituto jurídico muy utilizado en la práctica diaria, principalmente para encontrar objetos extraviados, personas desaparecidas, recabar información sobre el paradero de algún delincuente 0 , en el ámbito comercial, en la emisión de pagarés; sin embargo, no ha sido debidamente analizada por la doctrina jurídica nacional, a diferencia de lo que sucede en la doctrina comparada. Por ello, en el presente artículo se desarrolla un minucioso análisis de sus antecedentes históricos, su regulación en los códigos civiles más influyentes, su tratamiento en los códigos civiles del Perú, las clases de "verdaderas" promesas unilaterales y la regulación de la responsabilidad civil derivada del incumplimiento de una promesa unilateral.

Palabras clave: Promesa unilateral, declaración unilateral, responsabilidad civil, promesa de pública recompensa, promesa de pago, reconocimiento de deuda.

\begin{abstract}
:
The unilateral promise is a legal institution widely used in day to day practice, mainly to locate misplaced items, missing persons, gather information to find the whereabouts of a certain criminal, or, in the business realm, in the expenditure of promissory notes; however, it has not been dutifully analyzed by the national legal doctrine, opposed to what happens in comparative doctrine. Therefore, in this article we develop a thorough analysis of its historical precedents, its regulation in the most influential civil codes, how it has been treated by the Peruvian civil codes, the types of "true" unilateral promises and the regulation of the public liability derived from the breach of a unilateral promise.

Keywords: Unilateral promise, unilateral declaration, public liability, public reward promise, payment promise, debt acknowledgement.
\end{abstract}

“(...) pocos institutos están llenos de tanta oscuridad y generan tantas dudas como las promesas unilaterales."

\section{Carlos Alberto Graziani}

\section{ANTECEDENTES HISTÓRICOS DE LA PRO- MESA UNILATERAL}

La promesa unilateral es un instituto de antigua data. Su utilidad y la concepción que se tiene de ella han ido evolucionando con el transcurso del tiempo. Es por ello que previamente al análisis de la responsabilidad civil de la promesa unilateral, revisaremos sus antecedentes históricos, lo que nos permitirá: (a) identificar el hecho social que, por su importancia para una pacífica convivencia, se convirtió en un hecho jurídico; (b) conocer la concepción que sobre este instituto se tuvo en sus inicios; y (c) contrastar la función y utilidad que inicialmente tuvo la promesa unilateral con la que tiene en la actualidad.
Bajo tales premisas, a continuación, analizaremos a la promesa unilateral en el derecho romano, en el derecho canónico y en el derecho alemán.

\section{Derecho romano.}

Por regla general, las promesas unilaterales no eran obligatorias en el Derecho romano. En consecuencia, para que surja una relación obligatoria, era necesaria la presencia de dos voluntades. Así lo expresa, entre otros, Astuti:

“(...) la manifestación de la voluntad de obligarse es concebida constantemente como fuente de obligatio sólo en cuanto es configurable y configurada como contractus, mientras que la simple promesa unilateral no viene reconocida idónea a dar vida a un vínculo obligatorio"'.

Sin embargo, existieron dos excepciones a

1. ASTUTI, G. I contratti obbligatori nella storia del diritto italiano, cit. por Graziani, Carlo Alberto. "Le Promesse Unilaterali". En: Trattato di Diritto Privato, Tomo I, Vol. 9, Obbligazioni e contratti, diretto da Pietro Rescigno. Turín: UTET, 1988, p. 633. 
dicha regla: la pollicitatio y el votum. Así, por ejemplo, señala Sitzia:

"(...) En el debate, asaz vivo entre los civilistas en los primeros decenios de nuestro siglo sobre los problemas conexos a la promesa unilateral como fuente de obligaciones, era frecuente referirse a un instituto romano, la pollicitatio, que tradicionalmente se recordaba junto al votum, como hipótesis excepcional en la cual el ordenamiento romano habría reconocido la eficacia vinculante de la declaración unilateral independientemente de la aceptación del destinatario"2.

En uno de sus más recientes trabajos sobre esta materia, Recano también ha señalado que:

"(...) la promesa unilateral no habría constituido para el ordenamiento romano, una fuente general de obligaciones, siendo reconocida su vinculatoriedad, de manera excepcional, exclusivamente en el caso de la pollicitatio hecha a una res publica. La vinculatoriedad jurídica de la declaración unilateral promisoria estaba reconocida en relación con el votum, significativamente colocado en la compilación justinianea al lado del instituto antedicho"s.

Siguiendo esta misma corriente, Graziani señala que ambos institutos:

"(...) representaban para el derecho romano, al menos según la opinión prevaleciente, las únicas hipótesis en que la obligación nacía de la simple promesa unilateral, la cual, por tanto, podía ser comprendida entre aquellas variae causarum figurae que, en el listado de las fuentes de la obligación realizada por Gaio, se ponían al lado del contractus y del maleficium" ${ }^{4}$.

Como se puede apreciar, en el derecho romano se otorgó carácter obligatorio a estas dos especies de promesas unilaterales, lo que, en buena cuenta, constituyó el reconocimiento de una nueva fuente de obligaciones. Por ello, Sitzia señala que,

"(...) una doctrina plurisecular que se fundaba en el D. 50, 12, 3 pr. ${ }^{5}$ contraponía, en efecto, al pactum como acuerdo de dos sujetos (duorum consensus atque conventio), la pollicitatio como promesa unilateral (offerentis solius promissum), y afirmaba que esta última no habría producido, por principio general, algún efecto obligatorio, excepto en la hipótesis particular de la promesa a una res publica." ${ }^{6}$

Pero, ¿en qué consistían la pollicitatio y el votum?, ¿cuáles eran sus presupuestos y requisitos? y ¿cuáles sus efectos? A continuación, conoceremos cada una de estas expresiones de promesas unilaterales que fueron reconocidas en el derecho romano.

\subsection{La pollicitatio.}

La pollicitatio consistía en una promesa hecha por el ciudadano a la ciudad, al municipio o a la colonia, de construir una obra - pollicitatio operis faciendi- o de dar una suma de dinero

2. SITZIA, Francesco. "Promessa unilaterale (storia)". En: Enciclopedia del Diritto, Tomo XXXVII. Varese: Giuffrè, 1988, p. 22.

3. RECANO, Paolo. "Profili storici della promessa unilaterale". En: Rassegna di Diritto Civile, Tomo I, diretta da Pietro Perlingieri. Nápoles: Edizioni Scientifiche Italiane, 2006, p. 168.

4. GRAZIANI, Op. Cit., p. 633.

5. "Pactum est duorum consensus atque conventio, pollicitatio vero offerentis solius promissum" (Ulp. I. 4 disp.).

6. SITZIA, Op. Cit., p. 23. 
- pollicitatio pecuniae-, efectuada ya sea ob causam, o más precisamente, ob honorem, es decir, por asumir un cargo - para conferir o ya conferido-; o, según algunos intérpretes, sine causa, esto es, non ob honorem?.

De la definición trascrita, podemos extraer las siguientes características de la pollicitatio: (a) el destinatario de la promesa siempre era una entidad pública - ya sea una ciudad, una colonia o un municipio-; (b) en atención al objeto de la promesa, la pollicitatio podía ser: operis facendisi la promesa consistía en la construcción de una obra-, o pecuniae - si la promesa consistía en entregar dinero-y (c) en atención a la causa de la promesa, la pollicitatio podía ser: ob honorem u ob causam —si el promitente manifestó la promesa por la asunción de un cargo-, o non ob honorem o sine causa - si el promitente manifestó la promesa libremente, es decir, sin asumir un cargo-.

Respecto de las pollicitationes ob honorem, su obligatoriedad fue sancionada, por primera vez, en una constitución del emperador Trajano, reportada en el D. 50, 12, 14 - Pompon. I. 6 epist. et. var. lect.— ${ }^{8}$. Asimismo, Sitzia señala que: "(...) es considerada pollicitatio ob honorem la pollicitatio hecha con ocasión de la asunción de un cargo público o de una dignidad sacerdotal". En realidad, el título 50, 12 del Digesto atribuye eficacia vincu- lante a las pollicitationes ob honorem vel ob aliam iustam causam -D. 50, 12, I, I-"'.

De otro lado, respecto de la pollicitatio non ob honorem o sine causa, un importante sector de la doctrina niega su carácter obligatorio. Así, por ejemplo, Ascoli señala que "(...) la pollicitatio sine causa no era obligatoria a menos que hubiese sido ejecutada y limitadamente a cuanto haya sido eje-

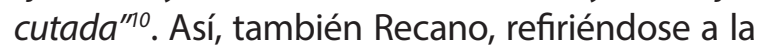
pollicitatio non ob honorem, afirma que,

"(...) la exigibilidad de la misma, sólo fue reconocida en los casos en que se hubiere dado inicio a la ejecución de las labores -inchoatio operis, coeptum opus-, en el caso de la pollicitatio operis; o que el promitente hubiere ejecutado un pago parcial, en la hipótesis de la pollicitatio pecuniae ${ }^{\prime \prime 1}$.

Por su parte, Sitzia, intentando explicar el fundamento de esta exigencia para la obligatoriedad de la pollicitatio non ob honorem, señala que "(...) la ratio que inspira la solución en examen se puede encontrar en la necesidad para la civitas de evitar la construcción de obras incompletas"12.

En efecto, en tanto que la pollicitatio non ob honorem o sine causa era realizada libremente por cualquier ciudadano romano, era probable

7. GRAZIANI, Op. Cit., p. 632. En cuanto a su origen, Sitzia, citando a Archi, señala que este instituto encuentra su origen "(...) en aquel espíritu de espléndida sociabilidad y liberalidad que parece haber sido tan arraigado en la vida de los municipios romanos al final de la república. Sin embargo, en aquel periodo, su sanción habría sido sólo social y moral; una sanción jurídica se daría sólo en un momento posterior, en la práctica de las singulares ciudades y, en un segundo momento, en el reconocimiento imperial." (Sitzia, Op. Cit., p. 24).

Por su parte, Martinez de Aguirre y Aldaz señala que la "(...) figura romana de la pollicitatio ha sido muy debatida entre los romanistas, por lo que se refiere a su naturaleza unilateral o bilateral, a su alcance obligacional, a su carácter público o privado y al momento histórico en que debe ser situada" (La Promesa pública de recompensa. Barcelona: BOSCH, 1985, p. 41).

8. "Si quis sui alienive honoris causa opus facturum se in aliqua civitate promiserit, ad perficiendum (tam ipse quam heres cius) ex constitutione divi Traiani obligatus est." (Recano, Op. Cit., p. 173).

9. SITZIA, Op. Cit., p. 26.

10. ASCOLI, A. La Pollicitatio, cit. por Graziani, Op. Cit., p. 632.

11. RECANO, Op. Cit., p. 174.

12. SITZIA, Op. Cit., p. 26. 
el incumplimiento total o parcial de dicha promesa, lo que hubiera generado, como señala Sitzia, la construcción de obras incompletas en caso de la pollicitatio operis- o el incumplimiento íntegro del pago - en caso de la pollicitatio pecuniae - . Para evitar estas situaciones se reconocía la obligatoriedad de la pollicitatio non ob honorem sólo cuando la prestación prometida había sido ejecutada.

Como hemos señalado, la pollicitatio constituyó para el derecho romano una de las expresiones de promesa unilateral obligatoria; sin embargo, cierto sector de la doctrina considera que esta fattispecie tuvo carácter bilateral. Dentro de este sector se encuentran, en primer lugar, Brini $y$, posteriormente, el ilustre romanista italiano Albertario. Así, el primero de los autores mencionados, señalaba que: "(...) la pollicitatio a la res publica habría tenido naturaleza de negocio bilateral, constituyendo el consenso de la civitas requisito para el surgimiento del vínculo en cabeza del promitente"1/3.

Por su parte, Albertario, haciendo propio los argumentos de su predecesor,

"(...) sacó provecho desde el punto de vista formal, la bilateralidad de la pollicitatio de dos textos del Digesto justinianeo -D. 50, 4, 16, 1, Paulo I sent. y D. 50, 12, 6, 1, Ulpiano 5 de off. proc.-, de los cuales prima facie, parecería inferirse que la vinculatoriedad de las pollicitationes pecuniae, inclusive realizada ob honorem, fuese ligada al cumplimiento par- cial de la prestación prometida. En la circunstancia que la civitas recibiese un pago parcial, el romanista reconocía una aceptación, si bien tácita, de sus órganos: el decaimiento de la obligatoriedad de la promesa por la ejecución parcial de la prestación que constituía su objeto era prueba, para el estudioso, de la necesidad del consenso de la res publica para que la pollicitatio deviniese obligatoria"14.

Un último tema a considerar sobre la pollicitatio, es el referido a su formalidad. Es conocido que una de las características más conspicuas del Derecho Romano es la formalidad que se exigía para la validez de los actos jurídicos; sin embargo, esto no sucedió con la pollicitatio, pues - como señala Archi, "(...) la pollicitatio requería la oralidad, sin que fuera necesario emplear determinadas palabras solemnes a fin de que la promesa sea válida." ${ }^{.15}$

\subsection{El votum.}

El votum era la promesa hecha a la divinidad de efectuar una prestación - por ejemplo, de pagar la décima - la cual no obligaba sólo desde el punto de vista religioso, sino también del $\mathrm{civi}^{16}$. En el derecho romano era usual que las personas expresen sus votos de fe, que no consistían en simples promesas de "no pecar", sino en la entrega de bienes materiales.

Recano señala que "(...) la obligatoriedad del votum en el período justinianeo resulta claramente del D. 50, 12, 2 -Ulp. I, disp.—-17, infiriéndose del

13. BRINI, G. "La bilateralità delle pollicitationes ad una res publica e dei vota nel diritto romano". Cit. por RECANO, Op. Cit., p. 172.

14. Albertario, E. La Pollicitatio. Cit. por ReCANO, Op. Cit., p. 177.

15. ARCHI, G. La pollicitatio in diritto romano. Cit. por RECANO, Op. Cit., p. 182.

16. GRAZIANI, Op. Cit., pp. 632-633.

17. "Si quis rem aliquam voverit, voto obligatur quae res personam voventis, non rem quae vovetur obligat. Res enim, quae vovetur, soluta quidem liberat vota, ipsa vero sacra non efficitur. 1. Voto autem patres familiarum obligantur puberes sui iuris: filius enim familias vel servus sine patris dominive auctoritate voto non obligantur. 2. Si decimam quis honorum vovit, decima non prius esse in bonis desinit, quam fuerit separata, et si forte qui decimam ante sepositionem, heres ipsius hereditario nomine decimae obstrictus est: voti enim obligationem ad heredem transire constat." (RECANO, Op. Cit., p. 182). 
fragmento también la transmisibilidad de la obligación en cabeza de los herederos del vovens"1"8.

Del fragmento trascrito del Digesto, extraemos con Sitzia' ${ }^{19}$ las siguientes tres conclusiones: (a) del votum nace una obligación y no un derecho real; (b) esta obligación puede ser contraída por un filiusfamilias o por un servus con la auctoritas del pater o del dominus; $y$ (c) ella es transmisible a los herederos.

En el derecho romano se reconocieron dos clases de votum: los vota privata y los vota publica. Visky señala que los primeros "(...) eran generalmente pronunciados con relación a intereses del Estado, en ocasiones extraordinarias o año por año. Era usual que los altos funcionarios del Estado pronunciaran sus votos al momento de la asunción del cargo; y los otros - los vota publica-, eran hechos en caso de guerra o de calamidades públicas" ${ }^{\prime 20}$. En cuanto a la forma, añade Visky que "(...) el votum era una promesa oral y solemne, para cuya validez era probablemente requerida, cuanto menos en el período arcaico, la pronunciación de palabras de carácter sagrado"21.

Como podemos apreciar, a diferencia de la poIlicitatio, el votum era un acto eminentemente formal, pues,

"(...) los vota publica, en particular, diferenciándose de aquéllos privata por ser pronunciados a salvaguardia de intereses del Estado, eran insertos en un texto redactado por el colegio de los pontifices, el cual, leído por el pontifex maximus, venía repetido inmediatamente después por el cónsul o el pretor: el particular procedimiento que era necesario realizar para llegar a la formulación de los vota publica revela aún más la solemnidad"22.

Añade Firpo, que: "(...) el cargo de verba praeire del pontífice máximo era necesaria para la perfecta realización del voto, ya que el pontifex controlaba que la fórmula fuese nuncupata y el rito concluido según las reglas" ${ }^{\prime \prime 2}$.

Si la formalidad constituyó una de las diferencias entre las dos promesas unilaterales reconocidas en el derecho romano, un aspecto coincidente entre ambas fue la polémica existente en torno a su naturaleza unilateral. Así, por ejemplo, Toutain ha afirmado que,

"(...) para el derecho romano, el vovens debía cumplir la promesa sólo después de que la divinidad hubiere atendido el requerimiento; asumiéndose que la asunción del pedido por parte de la divinidad implicaría su consenso para el surgimiento del vínculo, así, se demuestra la naturaleza bilateral del negocio"24.

\section{Derecho canónico: el iuramentum promi- sorio.}

Como hemos visto en el acápite precedente, el problema principal en el derecho romano era determinar la estructura de la promesa unilateral, esto es, la distinción bilateralidad-unilateralidad de la promesa. En el Derecho canónico, sucedió algo distinto, pues - como señala Gra-

18. RECANO, Op. Cit., p. 182.

19. SITZIA, Op. Cit., p. 30.

20. VISKY. II "votum" in diritto romano privato. Cit. por Sitzia, Op. Cit., p. 29.

21. VISKY. II "votum" in diritto romano privato. Cit. por Recano, Op. Cit., p. 183.

22. RECANO, Op. Cit., p. 183.

23. FIRPO, G. Votum. Cit. por RECANO, Op. Cit., p. 183.

24. TOUTAIN, J. Votum. Cit. por RECANO, Op. Cit., pp. 183-184. 
ziani, el problema de fondo de la promesa unilateral y su obligatoriedad se encontraría más bien en la relevancia y en la tutela de los simples pactos y promesas, y es sobre este perfil que la promissio simplex es mencionada unida al pactu-25.

En este período, la Iglesia proclamaba el siguiente principio: "peca tanto quien no cumple una convención concluida en la forma de la stipulatio como quien viola un simple pacto; tanto quien no mantiene una simplex promissio como quien no observa un juramento"26.

Se aprecia, entonces, que la influencia del aspecto religioso en el ámbito jurídico, tendría tal importancia que el simple iuramentum - llamado también juramento promisorio-, era una promesa obligatoria. Sin embargo, debemos precisar que el iuramentum era obligatorio no con la finalidad directa de satisfacer el interés del acreedor, sino, fundamentalmente, por una convicción religiosa de cumplir lo prometido.

Resaltando este aspecto de la tutela del iuramentum, Recano señala que,

"(...) el reconocimiento general del principio de la inidoneidad de la declaración del promitente a producir obligaciones, en defecto de aceptación del promisario, evidenció una fractura entre la valoración jurídica y la valoración ética: según la moral cristiana, quien no cumple la promesa peca, independientemente de la eventual manifestación de voluntad del promisario de beneficiarse $e^{\prime 27}$.
Añadiendo más adelante que:

“(...) inspirado más por una exigencia de represión del pecado que por una particular consideración del interés del promisario, el principio de la vinculatoriedad por el ordenamiento canónico del mero pacto, en el sentido de acuerdo no concluido en la forma de la stipulatio, no implicó todavía la inmediata tutela del promisario mismo, resultando las sanciones vinculadas al incumplimiento de la promesa, en principio, de carácter exclusivamente publicístico" ${ }^{\prime 28}$.

En el mismo sentido, Graziani señala que la atención de los canonistas estaba dirigida fundamentalmente a la cuestión de conciencia del promitente, quien es tenido "ad solvendum promissum" para evitar el pecado; la satisfacción del interés patrimonial del promisario era sólo un efecto indirecto y eventual ${ }^{29}$.

Si se afirmaba que el iuramentum promisorio era obligatorio, entonces el ordenamiento jurídico canónico debió prever una sanción ante su incumplimiento. En efecto, refiriéndose a este aspecto, Dell'aquila señala que se imponía:

“(...) comúnmente, la condictio ex canone - así llamada con referencia al c. Juramento del Decretum Gratiani -, que permitía la actuación forzosa de la prestación; ello fue así salvo el breve paréntesis supuesto por Inocencio IV - Sinibaldo de Fieschi- para quien la simple promesa no disponía de protección procesal directa, sino de la indirecta amena-

25. GRAZIANI, Op. Cit., p. 634.

26. "Nota quoad observantiam Deus nullam differentiam vult esse inter simplicem promissionem et iuramentum vel aliter firmatam promisiones... Sive ergo interveniat stipulatio sive non, promissor non excusatur a peccato nisi adimpleat promissum, si potest" (Fedele, P. Considerazioni sull 'efficacia dei patti nudi nel diritto canonico. Cit. por GRAZIANI, Op. Cit., p. 634).

27. RECANO, Op. Cit., p. 193.

28. Ibíd, p. 191.

29. GRAZIANI, Op. Cit., p. 634. 
za de excomunión que suponía la denuntiatio evangelica" ${ }^{130}$.

Sin embargo, debemos precisar que en el derecho canónico no toda promesa era obligatoria, sino sólo las que tenían la calidad de iuramentum, para lo cual era necesario cumplir ciertos requisitos. El más importante de ellos era que la promesa se haya sustentado en una justa causa. Así, por ejemplo, Bellini señala que "(...) la condición para que el promisario pueda hacer valer en juicio su derecho es la existencia de una idónea causa promissionis, que sea tal para justificar la función del negocio en la vida social de relación"31.

En el mismo sentido, señala Recano:

“(...) la communis opinio de los canonistas fue que la promesa no aceptada no podía producir, en línea de principio, obligaciones. A las promesas dirigidas a la divinidad y a la res publica, que el derecho romano ya conocía, se sumaban las promesas unilaterales vinculadas a aquéllas hechas por pías causas. ${ }^{132}$

Añadiendo, más adelante que "(...) excepcionalmente se reconoció la obligatoriedad de la promesa unilateral en caso que fuese dirigida a la colectividad pública aunque fundada sobre una justa causa. ${ }^{133}$

Además del requisito de la justa causa, se exigía que la promesa sea acorde a la moral. Sobre este requisito, Pertile señala que:

“(..) a través del juramento se otorgaba efi- cacia también a obligaciones que el derecho civil rehusaba reconocer. Puesto que tanta era la eficacia que les atribuía el derecho canónico, que era válido constituir una propia obligación cada vez que la promesa fuese moralmente lícita, y también cuando ella no contraviniese el derecho de los terceros (... $)^{1 / 34}$.

No obstante lo expuesto, al igual que en la poIlicitatio, también existe un sector de la doctrina que niega carácter obligatorio a las promesas unilaterales en el derecho canónico, pues consideraba que era necesaria su aceptación. Este sector sustenta su afirmación indicando que la sanción ante el incumplimiento de una promesa unilateral sería de difícil realización, pues el can. 1318, par. 1 del Codex de 1918, confirmado integralmente por el can. 1201, par. 1 del nuevo Codex, señalaba que:

"el juramento promisorio, esto es, el juramento con el que se promete un hecho futuro, no obliga antes de la aceptación del promisario, y que el promitente siempre puede revocarlo, incluso hasta el momento de la aceptación ${ }^{135}$.

\section{Derecho alemán: el auslobung.}

Hemos visto, según la tradición romana que, en línea de principio, la declaración unilateral de voluntad no generaba obligaciones. Tal situación fue objeto de una profunda revisión crítica en el siguiente siglo por un importante jurista alemán Ilamado Heinrich Siegel.

Para Siegel, en el derecho alemán antiguo, a

30. DELL`AQUILA. "La promesa unilateral como fuente general de obligaciones". Cit. por MARTÍNEZ DE AGUIRRE, Op. Cit., p. 48.

31. BELLINI, P. L'obbligazione da promessa con oggetto temporale nel sistema canonistico classico. Cit. por GRAZIANI, Op. Cit., p. 638

32. RECANO, Op. Cit., p. 192.

33. Ibíd, p. 190.

34. PERTILE. Storia del diritto italiano. Cit. por SITZIA, Op. Cit., p. 31.

35. P VERMEERSCH, A. y CREUSEN, J. Epitome luris Canonici, cit. por GRAZIANI, Op. Cit., p. 636. 
diferencia del derecho romano, la promesa unilateral genera obligaciones. Sustentaba su tesis señalando, a propósito de la formación del contrato, que, mientras en la stipulatio romana era el acreedor quien lanzaba la promesa - Spondesne? Spondeo-, en la concepción alemana, el contrato se formaba con la promesa del deudor seguida de la aceptación del acreedor. En otros términos, los alemanes descomponían el contrato no en una oferta - demanda - y en una aceptación como hacían los romanos, sino en una promesa y en una aceptación, considerando la promesa, desde el punto de vista conceptual, como la fase precedente y la aceptación como absolutamente subordinada frente a la promesa; ella incluso se iba reduciendo hasta quedar convertida en una presunción. A quienes veían una aceptación en el comportamiento concluyente del aceptante $y$, en particular, en su pedido de cumplimiento de la promesa o en la interposición de la demanda judicial, Siegel señalaba que aquél que pretende lo que ha sido prometido no quiere con ello hacer válida y eficaz dicha promesa porque sabe que ella ya es tal. El ordenamiento jurídico justamente porque reconoce como fundada dicha pretensión considera válida y eficaz la promesa no acepta$\mathrm{da}$, es decir, la promesa unilateral ${ }^{36}$.

Para dar fuerza a su argumentación, Siegel comparó a la promesa unilateral con otra fuente de obligaciones, en la que para el surgimiento de la obligación tampoco se requiere la voluntad del acreedor, demostrando de tal manera que no todas las fuentes de las obligaciones requieren la voluntad de dos partes. Así, el autor alemán señaló que "(...) el ilícito extracontractual produce el surgimiento de la obligación en cabeza del dañante, también en ausencia de una manifestación de voluntad del acreedor dañado"137.
La aparición de la tesis de Siegel generó polémica en la doctrina no sólo alemana, sino también francesa e italiana. Así, por ejemplo, Mirabelli, señaló que esta teoría "(...) movió los cimientos del sistema pandectístico que aún seguía la clasificación Gaiana y Justinianea de las fuentes de las obligaciones $^{138}$. Luego de expuesta y divulgada la tesis de Siegel, algunos autores llegaron a afirmar que la promesa unilateral debía ser considerada fuente general de obligaciones; otros, entre los que se encontraba Siegel, afirmaban la fuerza obligatoria sólo en casos particulares previstos por la ley o por la costumbre.

Sin embargo, Siegel no fue el único autor alemán que reconocía efectos obligatorios a la promesa unilateral. Kuntze, en el prólogo a su libro Die Lehre von den Inhaberpapieren - Leipzig, 1857-, también defendía la obligatoriedad de la declaración unilateral de voluntad respecto de los títulos al portador, por ello se habría generado una controversia sobre la paternidad de esta teoría. Sin embargo, como señala Martínez de Aguirre,

\section{“(...) parece que Siegel la había defendido ya en una conferencia pronunciada en Giessen en 1854; y el mismo Siegel cita un párrafo de una carta que le envió uno de sus amigos con motivo de la aparición del libro de Kuntze, del que resultaba que la idea de la promesa uni- lateral obligatoria era ya antigua en Siegel (...), - añadiendo más adelante que - por la amplitud de su estudio (no restringido a los títulos al portador), por su profundidad y por su influencia en la doctrina posterior, la dis- cutida paternidad de la teoría citada corres- ponde a Siegel." 139}

Es así que en Alemania, desde mediados del siglo XVIII la generalidad de la doctrina admite

36. SIEGEL, H. Das Versprechen als Verpflichtungsgrund im heutigen Recht. Cit. por GRAZIANI, Op. Cit., p. 638.

37. SIEGEL, cit. por RECANO, Op. Cit., p. 202.

38. MIRABELLI, G. Promessa unilaterale. Cit. por GRAZIANI, Op. Cit., p. 639.

39. MARTÍNEZ DE AGUIRRE, Op. Cit., p. 44. 
la eficacia de la promesa de pública recompensa — auslobung-. Así, por ejemplo, la primera regulación de este instituto la encontramos en 1794, en el Allgemeiner Landrecht fur die Preussischen Staaten, I, 11, Artículo 988, que señalaba: "A todos es permitido proponer promesas públicas por trabajos intelectuales útiles o por empresas o manifestaciones de la actividad corporal, redundantes en utilidad general"40.

Posteriormente, diversos proyectos de códigos germanos han contemplado esta figura en el S. XIX, así por ejemplo, el Proyecto de Código Civil del Gran Ducado de Hessen -1853-, parte II, Artículo 198-206, el Código de Baviera -1861_, parte II, Artículos 753-761; y los Códigos de Sajonia de 1860 y 1863 -Artículos. 793 y 771 , respectivamente-.

\section{Apostilla.}

Al inicio habíamos señalado tres propósitos para estudiar los antecedentes históricos de la promesa unilateral. Pues bien, luego de haber conocido grosso modo sus manifestaciones en el derecho romano, en el derecho canónico y en el derecho alemán, vemos que nuestros dos primeros propósitos han sido satisfechos, pues ya hemos identificado las conductas que calificaban como promesas unilaterales y las razones por las que fueron reguladas. Asimismo, hemos conocido las diversas concepciones que se tuvieron en dichos períodos.

Respecto del tercer propósito, referido a la función que se otorgó a la promesa unilateral en la antigüedad, en comparación con la que se le otorga en la actualidad, debemos indicar que las promesas unilaterales reconocidas en el derecho romano - pollicitatio y votum - y en el derecho canónico -iuramentum promissoriose han circunscrito al derecho público y al derecho sagrado; sin embargo, en la actualidad, la promesa unilateral tiene una importancia, más bien, en el derecho privado.
Las diferencias son notorias, ya que en la actualidad las personas que asumen cargos públicos no realizan promesas para construir obras públicas o para entregar dinero; tampoco se promete entregar bienes materiales a favor de la Iglesia, o, si se hace, tal promesa no tiene carácter obligatorio, salvo que revista la forma de un contrato de donación. Ello evidencia que tales costumbres han desaparecido en nuestros días.

La utilidad que la sociedad actual otorga a la promesa unilateral es más bien servir como instrumento para encontrar objetos extraviados, personas desaparecidas o recabar información sobre el paradero de algún delincuente - promesas de pública recompensa-. Por su parte, en el ámbito comercial, la utilidad de la promesa unilateral la encontramos en los pagarés, mediante los cuales las personas prometen pagar una determinada cantidad de dinero a favor de otra, a través de la emisión de títulos que sirven para agilizar el tráfico de las relaciones comerciales.

De lo expuesto podemos concluir en que, no obstante las distintas utilidades que las sociedades — de acuerdo a sus necesidades - han otorgado a la promesa unilateral, todas ellas han considerado de vital importancia otorgarle efectos obligatorios.

\section{LA PROMESA UNILATERAL EN LA LEGIS- LACIÓN COMPARADA}

Una vez ya estudiado los antecedentes históricos de la promesa unilateral, ahora conoceremos la forma en que actualmente la legislación comparada regula a este instituto. Así, tenemos que el primer código civil en reconocer a la promesa unilateral como fuente de obligaciones fue el Código Civil alemán de 1900. Desde ese momento, muchos códigos han seguido tal corriente dedicando algunos de sus artículos a regular supuestos que constituyen promesas unilaterales.

40. La traducción ha sido tomada de Candil, cit. por Martínez de Aguirre, Op. Cit., p. 63. 
Así, el autor argentino Enrique Galli ${ }^{41}$ considera que, en el continente americano, los códigos que regularon de manera decidida a la promesa unilateral como fuente autónoma de obligaciones, son los siguientes: (a) El Código Civil brasileño de 1916 —Libro III, Título VI: “De las obligaciones por declaración unilateral de voluntad", en los artículos 1507 a 1517-; (b) El Código Civil mexicano para el distrito y territorios federales de 1928 — Libro IV, primera parte, Título 1ㅇ, Capítulo II: "De la declaración unilateral de la voluntad", en los artículos 1860 a 1881-; y (c) El Código Civil peruano de 1936 —Libro V, Sección VI: "De las obligaciones provenientes de la voluntad unilateral", en los artículos 1802 a 1822-.

Asimismo, consideramos importante conocer la forma en que algunos códigos han regulado a la promesa unilateral. No pretendemos con esto utilizarlos como modelos y realizar una "importación" de normas de la que ya tenemos malas experiencias, sino simplemente contrastar tales normas con las que contiene nuestro Código $\mathrm{Ci}$ vil. Para ello, hemos seleccionado a los tres códigos más importantes, por la influencia que han tenido en diversos ordenamientos jurídicos contemporáneos. Nos referimos al Code Civil francés, al BGB alemán y al Codice Civile italiano.

\section{El Code Civil francés.}

El Código Civil francés -o simplemente, el Code Napoleon - ${ }^{42}$ fue uno de los primeros códigos civiles en promulgarse ${ }^{43}$. En 1804, año en que se promulgó este código, aún no se había postulado la tesis de la promesa unilateral como fuente de obligaciones.
No obstante la diversidad de modificaciones que ha sufrido este código, ninguna de ellas ha propuesto incluir a la declaración de voluntad como fuente de las obligaciones. Ello se debe en gran medida a que la doctrina francesa, casi de manera unánime, es partidaria de la tesis contractualista.

\section{EI BGB alemán.}

El Bürgerliches Gesetzbuch -en adelante, "BGB" - fue publicado el 18 de agosto de 1896, entrando en vigencia recién a partir del 1 de enero de 1900. Muchos han sido los elogios recibidos por el BGB. Así, por ejemplo, De Castro y Bravo ha señalado que

"El Código civil alemán es la creación más perfecta y brillante de la ciencia jurídica alemana. Obra científica de una época de gran madurez, en su redacción no interviene la pasión ni el entusiasmo político o reformador, sino que se caracteriza por su precisión y frialdad." ${ }^{\prime 4}$

El Código Civil alemán no destina un Título especial para regular los supuestos de promesas unilaterales, sino más bien los regula de manera dispersa. Así, por ejemplo, en el Título IX de la Sección Sétima denominada: "Relaciones Obligatorias en particular", regula a la promesa pública. Es importante resaltar el nombre de la Sección: "Relaciones Obligatorias" - y no "Contratos"-, lo que demuestra que los supuestos regulados en esta sección generan obligaciones no por el hecho de ser contratos, sino porque la voluntad unilateral per se constituye fuente de obligaciones.

41. En: Prólogo al Libro de BOFFI, Luis. La Declaración Unilateral de Voluntad como fuente de las obligaciones. Buenos Aires: Editorial Jurídica, 1942, pp. 19-20.

42. El Código Civil francés fue publicado el 21 de marzo de 1804. La denominación Code Napoleón fue realizada mediante Ley del 3 de setiembre de 1807.

43. Fue uno de los primeros, aunque no el primero, ya que tal lugar corresponde a uno de los Códigos de Baviera: El Codex Maximilianus Bavaricus Civilis dictado en 1756. Posteriormente, se promulgó el Código Prusiano (Allgemeines Landrecht, $A L R)$, que permaneció en vigor en el Estado de Prusia hasta la entrada en vigencia del Bürgerliches Gesetzbuch (BGB) el 1 de enero de 1900. RAMOS, Carlos. El Código Napoleónico y su recepción en América Latina. Lima: PUCP, 1997, pp. 55-56.

44. En: MELÓN, Carlos. Código Civil Alemán (BGB). Barcelona: BOSCH, 1955, pp. IX - X. 
En el artículo 657 define los alcances de la promesa pública, en los términos siguientes:

"Quien ofrece por medio público de divulgación una recompensa por la ejecución de un acto, en especial por la motivación de un resultado, está obligado a satisfacer la recompensa a aquél que ha realizado el acto, aunque éste no haya actuado en atención a la promesa".

Esta norma es muy parecida a nuestro artículo 1959, que señala:

"Aquél que mediante anuncio público promete unilateralmente una prestación a quien se encuentre en determinada situación o ejecute un determinado acto, queda obligado por su promesa desde el momento en que ésta se hace pública".

De las normas trascritas, advertimos dos diferencias: (a) en primer lugar, el Código alemán sólo hace referencia al supuesto de realizar un acto, mientras que nuestro Código, además de dicho supuesto, se refiere a "encontrarse en una situación determinada"; (b) por otro lado, el BGB hace bien en resaltar que no interesa que la persona que cumpla el acto requerido haya actuado en atención a la promesa, pues igual será acreedor de la recompensa por el simple hecho de cumplir el acto indicado en el anuncio público; ello evidencia un distanciamiento expreso de la concepción contractualista de este instituto. Por su parte, el artículo del código peruano no dispone tal situación, aunque en nuestra opinión, debe ser interpretado en ese sentido.

Los siguientes artículos del BGB son muy similares a los artículos del Código Civil peruano. Así, por ejemplo, el artículo 658 regula la revocación de la promesa pública, que también es regulado en los artículos 1963 a 1965 del Código Civil peruano; los artículos 659 y 660 regulan el supuesto en que el acto haya sido realizado por varias personas y la división de la recompensa, que es regulado por los artículos 1960 y 1961 del Código Civil peruano; finalmente el artículo 661 regula la promesa de prestación como premio de un concurso, al igual que los artículos 1966 y 1967 de nuestro código.

El otro supuesto de promesa unilateral que regula el BGB son los títulos valores. Estos se encuentran regulados a lo largo de 16 artículos -artículos 793 a 808-, dentro del Título 22, denominado "Obligación al portador". El artículo 793 señala que:

"Si alguien ha emitido un documento en el que promete una prestación al portador del mismo (obligación al portador), dicho portador puede exigir de él la prestación de conformidad con la promesa, a no ser que no esté autorizado a disponer del documento (...)".

La promesa unilateral que se emite a través de los títulos valores fue también regulada en el Código Civil de 1936 —artículos 1802 a 1815-; sin embargo, el Código Civil de 1984 no la regula, toda vez que se encuentra prevista en una ley especial - Ley 27287, Ley de Títulos Valores-.

Finalmente, la promesa de pago y el reconocimiento de deuda, que son regulados por el Código Civil peruano como promesas unilaterales en el artículo 1958, han sido regulados por el BGB como contratos. Así, el artículo 780 señala que:

"Para la validez de un contrato por el cual es prometida una prestación de forma que la promesa debe originar en sí misma la obligación (promesa de deuda)45, es necesario, en tanto no esté prescrita otra forma, otorgamiento escrito de la promesa."

El artículo 781 dispone que:

"Para la validez de un contrato por el cual es reconocida la existencia de una relación obligatoria (reconocimiento de deuda) ${ }^{46}$ es nece-

45. El paréntesis -señala Melón- figura como aclaración en el texto alemán. MELÓN, Op. Cit., p. 160.

46. Vid. nota anterior. 
sario otorgamiento escrito de la declaración de reconocimiento. Si está prescrita otra forma para el origen de la relación obligatoria cuya existencia es reconocida, requiere esta forma el contrato de reconocimiento".

Y el artículo 782 establece que: "Si una promesa de deuda o un reconocimiento de deuda son otorgados en base a una liquidación o por vía de la transacción, la observancia de la forma escrita prescrita en los parágrafos 780 y 781 no es necesaria".

\section{El Codice Civile italiano.}

El Código Civil italiano —en adelante, "Codi$c e^{\prime \prime}-$ es, sin duda, el código civil que ha ejercido mayor influencia en el Código Civil peruano vigente. Para corroborar ello basta con apreciar los artículos que regulan los contratos. El Codice fue publicado por Real Decreto del 16 de marzo de 1942, entrando en vigencia desde el 21 de abril del mismo año. Un aspecto que llama la atención es la cantidad de artículos que contiene. Nada menos que 2969 artículos, esto es, 847 más que nuestro Código Civil vigente.

El Codice regula a las promesas unilaterales dentro de su Libro Cuarto: "De las Obligaciones", en dos títulos: (a) El título IV: "De las promesas unilaterales" y (b) El Título V: "De los Títulos de Crédito".

Cinco son los artículos que regulan las promesas unilaterales —artículos 1987 a 1991-. El artículo 1987 prescribe que la promesa unilateral no produce efectos obligatorios fuera de los casos admitidos por la ley; por su parte, el artículo 1957 de nuestro Código contiene una disposición similar, pero no sólo se limita a los casos previstos por la ley, sino indica que las promesas unilaterales también serán obligatorias si existe un acuerdo previo entre las partes interesadas.

El artículo 1988 del Codice regula la promesa de pago y el reconocimiento de deuda señalando que ambos dispensan a aquél a favor del cual se hace de la carga de probar la relación fun- damental; supuestos de hecho y consecuencias jurídicas similares son reguladas por el artículo 1958 del Código Civil peruano.

Por su parte, el artículo 1989 del Codice reconoce como promesa unilateral a la promesa de pública recompensa y regula el plazo de vigencia de la misma; el artículo 1959 del Código Civil peruano regula los alcances de la promesa de pública recompensa, mientras que su plazo de vigencia es regulado en el artículo 1962.

Asimismo, la revocación de la promesa pública y el supuesto en que varias personas realizan el acto de manera separada son regulados en los artículos 1990 y 1991, respectivamente; dichos supuestos se encuentran en los artículos 1960, 1963 y 1964 de nuestro Código Civil.

Finalmente, respecto de los títulos valores, debemos señalar que el Código Civil italiano los regula a lo largo de 36 artículos -artículos 1992 a 2027-. Como ya hemos indicado, el ordenamiento jurídico peruano ya no regula a los Títulos Valores en el Código Civil, sino en una ley especial — Ley 27287, Ley de Títulos Valores-.

\section{BREVE EXCURSUS SOBRE LA PROMESA UNILATERAL EN LA LEGISLACIÓN PE- RUANA}

Realizar un estudio sobre la regulación que el ordenamiento jurídico peruano ha otorgado a la promesa unilateral en los distintos cuerpos legislativos implica conocer la evolución del pensamiento de la sociedad peruana sobre el instituto en referencia, toda vez que la legislación es -o debe ser- el reflejo de las necesidades de una sociedad en un tiempo y espacio determinados.

Comoquiera que consideramos de capital importancia conocer tal aspecto, a continuación realizaremos un breve análisis de la forma en que se ha regulado a la promesa unilateral en los tres códigos civiles que han regido la vida republicana del Perú: el Código Civil de 1852, el Código Civil de 1936 y el vigente Código Civil de 1984.

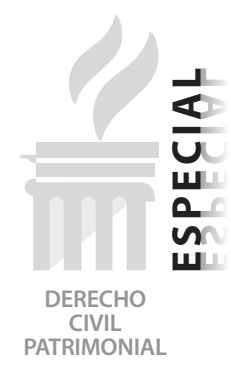

CIVIL
PATRIMONIAL 


\section{Código Civil de 1852.}

De los tres códigos civiles que han estado vigentes en el Perú47, el Código Civil de 1852 ha sido el más longevo - 84 años - , toda vez que el Código de 1936 sólo estuvo vigente 48 años, mientras que el actual código civil hasta la fecha está vigente 32 años, sin embargo ya se ha creado una Comisión que estudia su reforma ${ }^{48}$.

El Código Civil de 1852 —también conocido como Código de Echenique- $-{ }^{49}$ no regulaba a la promesa unilateral. Esto era entendible, toda vez que la corriente que consideró a la promesa unilateral como una fuente de obligaciones surgió recién 22 años después de su entrada en vigencia.

\section{Código Civil de 1936.}

El Código Civil de 1936 fue el primer código civil peruano que reguló a la promesa unilateral como fuente de obligaciones. Sin embargo, la incorporación de tales normas no fue tarea fácil; por el contrario, dio lugar a una interesante discusión entre dos importantes juristas de esa época: Manuel Augusto Olaechea y Pedro Oliveira.

Refiriéndose a este debate, señala De La Puente:

"Al proponer a la Comisión Reformadora del Código Civil el Plan del Libro V del Proyecto, Manuel Augusto Olaechea planteó la conve- niencia de que la sección sexta de dicho Libro se ocupara como novedad legislativa que las costumbres reclamaban, de las obligaciones provenientes de la voluntad unilateral que debían constar de dos títulos que versarían, respectivamente, de los títulos al portador y de la recompensa. En su pliego de observaciones a la ponencia de Olaechea, Pedro Oliveira manifestó que aunque se tuviera la voluntad unilateral como fuente de las obligaciones, por construcción técnica sólida de noble abolengo romano, habría que reconocer que en el estado actual (1923) de los estudios jurídicos, no constituía una categoría incontrovertible con derecho a ocupar un puesto en las clasificaciones legislativas.

Olaechea, citando a Bevilaqua, refutó que la clasificación de las materias del derecho obligacional exigía que se incluyera esos títulos, bajo pena de quebrar la lógica del sistema. Oliveira volvió a presentar a la Comisión un Memorándum de observaciones a la réplica de Olaechea, en el cual indicó que la razón de su posición era que la voluntad unilateral como fuente de las obligaciones no constituía aún una construcción jurídica definitivamente incorporada a la ciencia y a la legislación.

Tan interesante debate continuó con una nueva argumentación de Olaechea quien opinó que la doctrina de la voluntad unilateral parecía generalmente admitida por los tratadistas,

47. Es necesario precisar que antes del Código Civil de 1852 estuvo vigente el Código Civil Santa Cruz del Estado Sud-Peruano, promulgado el 22 de junio de 1836, que abarcaba los departamentos de Arequipa —incluyendo Moquegua, Tacna, Arica y Tarapacá-, Ayacucho, Cuzco y Puno; y el Código Civil Santa Cruz del Estado Nor-Peruano promulgado el 01 de noviembre de 1836, que abarcaba los departamentos de Amazonas, Junín, La Libertad y Lima. RAMOS, Carlos. Historia del Derecho Civil Peruano, Siglos XIX y XX. Tomo II. La codificación de la Confederación y el Código Civil de 1852. Lima: PUCP, 2001, pp. 71 y 74.

48. Esta situación ha provocado un interesante debate entre quienes están a favor de la reforma (BENAVIDES, Eduardo. "La Reforma del Código Civil Peruano sobre el Derecho de los Contratos, parte general ¿En busca de una isla?". En: ADVOCATUS, № 7, Lima: 2002, pp. 393-408) y quienes están en contra. CASTILLO FREYRE, Mario. "La Isla de la Fantasía (o la vieja y absurda idea de modificar un Código que recién va a cumplir la mayoría de edad)". En: Actualidad Jurídica, T. 103, Lima: 2002, Gaceta Jurídica, pp. 9-21.

49. Para un estudio evolutivo de este código, véase: CÁRDENAS, Carlos. "El Código Civil del Perú de 1852 (Aproximación histórico-legislativa y comparativa)". En: Estudios de Derecho Privado (Reflexiones de un tiempo), Tomo I, Ediciones Jurídicas. Lima: 1994, pp. 651-694. 
agregando que el Anteproyecto destacaba sólo dos figuras de la voluntad unilateral: los títulos al portador y las promesas públicas de recompensa, pero que otras manifestaciones del mismo fenómeno afloraban en el Anteproyecto. La Comisión Reformadora aprobó el planteamiento de Olaechea. ${ }^{1150}$

Este debate también ha sido reseñado por Josefina Vallejo, quien, en su interesante tesis referida a la declaración unilateral de voluntad en el Código Civil de 1936, señala lo siguiente:

"Hubo en el curso de este debate discusión doctrinaria profunda al respecto. El Dr. Oliveira con razonamiento claro $i$ preciso se opuso a que se incorporase en el articulado de nuestro Código las disposiciones sobre la declaración de voluntad unilateral; pues consideraba prematuro, ya que la institución todavía no había alcanzado la madurez necesaria como para adquirir carta de ciudadanía en nuestro derecho positivo". En respuesta a ello, Olaechea: "considera el Código como un instituto de evolución que ha ganado en dinamicidad i adquirido mayor pujanza vital, $i$ por consiguiente debe contener disposiciones elásticas i previsorias que en el futuro pueda albergar instituciones que actualmente flotan en el ámbito jurídico del mundo" ${ }^{\prime \prime 51}$.

Como se puede apreciar de los párrafos trascritos, fue ardua la tarea para lograr que el Código Civil de 1936 incorpore a la promesa unilateral como una fuente más de las obligaciones, pero tal propósito, finalmente, fue conseguido.

El Código Civil de 1936 regulaba a la promesa unilateral en el Libro Quinto, Sección Sexta "De las obligaciones provenientes de la voluntad unilateral". En esta sección se encontraban regulados dos supuestos de promesas unilaterales: en el Título I, los Títulos al Portador —arts. 1802 a 1815-, y en el Título II, la promesa de recom- pensa -arts. 1816 a 1822-. A continuación, citaremos las normas más importantes del Código Civil de 1936 sobre la promesa de recompensa e indicaremos en qué normas del Código Civil de 1984 se regulan dichos supuestos.

El artículo 1816 del código de 1936 contiene la definición de la promesa de recompensa, señalando que: "El que por medio de anuncios públicos prometa recompensar a quien ejecute determinado acto, contrae la obligación de cumplir lo prometido", mientras que el artículo siguiente reiteraba lo dicho: "Cualquiera que realice el acto, puede exigir la recompensa prometida". Estas normas son similares a la contenida en el artículo 1959 del Código de 1984; sin embargo, ésta es más amplia al indicar no sólo "un determinado acto", sino también "a quien se encuentre en una determinada situación".

El artículo 1818 del Código Civil de 1936 señalaba que:

"La promesa pública de recompensa podrá retirarse antes de la ejecución; pero la retractación sólo producirá efecto cuando lo hiciere del mismo modo que la promesa. Podrá el promitente renunciar anticipadamente al derecho de revocar la promesa. La fijación de un plazo para ejecutar el acto implica la renuncia de revocar la promesa durante dicho plazo".

Los supuestos que contiene este artículo están regulados en los artículos 1963, 1964 y 1965 del código vigente.

Por su parte, el artículo 1819 del código de 1936 señala que:

"Si el hecho por el cual se prometió la recompensa se hubiese ejecutado por varios, tendrá derecho a recibir el que primero realizó la ejecución. Si el hecho fue ejecutado simultáneamente por varios, cada uno recibirá una par-

50. DE LA PUENTE Y LAVALLE, Manuel. Estudios sobre el Contrato Privado. Tomo I. Lima: Cultural Cuzco, 1983, pp. 80-81.

51. VALLEJO LLONTOP, Josefina. La Declaración de Voluntad Unilateral en el Código Civil de 1936. Tesis para el Bachillerato en Derecho y Ciencias Políticas. PUCP, Lima, 1943, pp. 20-21. 
te igual de recompensa. Si la recompensa no es divisible, o si según el tenor de la promesa, hubiere de obtenerla uno solo, lo decidirá la suerte".

El artículo 1960 del Código Civil de 1984 también regula el supuesto en que varias personas hayan ejecutado el acto; sin embargo, la solución que establece no es la de entregar la recompensa al primero que realizó el acto, sino al primero que haya dado noticia de tal hecho.

El artículo 1820 del Código Civil de 1936 regula el supuesto en que varias personas hayan cooperado para realizar el acto solicitado por el promitente; así, dicho artículo señalaba lo siguiente:

"Si varias personas hubieran cooperado al objeto para el cual se prometió la recompensa, deberá el promitente distribuir la recompensa entre todos, teniendo en cuenta la equidad de la distribución. Si alguno de los interesados en la recompensa impugnare la distribución acordada por el promitente, podrá éste suspender la distribución hasta que los interesados arreglen entre sí las diferencias suscitadas. Cualquiera de ellos puede pedir que se deposite la recompensa a nombre de todos (...)".

El artículo 1961 del código vigente regula el mismo supuesto, estableciendo también que se deberá dividir equitativamente entre las personas que hubieran cooperado, pero añade un criterio objetivo para tal división: "atendiendo a la parte que cada una tuviera en el resultado". Sin embargo - a diferencia del código de 1936el código vigente no regula expresamente el supuesto en que uno de los promisarios impugne la decisión del promitente en la distribución de la recompensa.

Finalmente, el Código Civil de 1936 reguló la promesa de recompensa como premio de un concurso, en los artículos 1821 y 1822. El primero de ellos, señaló lo siguiente:

"La recompensa prometida como premio de un concurso no será válida sino cuando el anuncio fije un plazo para la ejecución. La cuestión relativa a determinar si un concursante ha satisfecho las condiciones del concurso, o cuál de los concursantes merece la preferencia, se decidirá por la persona designada en la promesa, y a falta de esta designación, por el mismo promitente, siendo obligatoria en ambos casos la decisión. Cuando todos los concursantes tuvieran el mismo mérito, se adjudicará la recompensa con sujeción a lo dispuesto en el segundo o tercer párrafo del artículo 1819".

Por su parte, el artículo 1822 dispuso que: "El promitente sólo podrá exigir la propiedad de la obra premiada cuando haya estipulado esta condición en la promesa". Los artículos 1966 y 1967 del Código Civil de 1984 otorgan una regulación similar a la transcrita.

\section{Código Civil de 1984.}

El Código Civil vigente también consideró a la promesa unilateral como fuente de obligaciones. Para corroborar ello basta apreciar su ubicación - Sección Quinta del Libro VII que lleva por título: Fuente de las Obligaciones-.

En la referida Sección Quinta se regulan los siguientes supuestos de promesas unilaterales: la promesa de pago, el reconocimiento de deuda, la promesa de pública recompensa y la promesa como premio de un concurso. A diferencia del Código Civil de 1936, los títulos valores han sido regulados en una ley especial, la Ley 27287.

\section{LA PROMESA UNILATERAL EN EL CÓDIGO CIVIL PERUANO}

\section{El artículo 1956.}

El artículo 1956 del Código Civil señala lo siguiente:

"Por la promesa unilateral el promitente queda obligado, por su sola declaración de voluntad, a cumplir una determinada prestación en favor de otra persona. Para que el destinatario sea acreedor de la prestación es necesario su asentimiento expreso o tácito, el 
cual opera retroactivamente al momento de la promesa."

La primera parte del artículo es bastante clara y evidencia la postura adoptada por nuestro legislador respecto de la admisibilidad de la promesa unilateral como fuente de obligaciones: basta la sola promesa de una persona para que ésta quede obligada a cumplir una prestación a favor de otra. Del texto de la norma trascrita y de su ubicación - dentro del Libro VII: Fuente de las Obligaciones-, podemos concluir que en nuestro país, la promesa unilateral sí es capaz de generar obligaciones. Ésa es la primera conclusión a la que se puede arribar del texto y de la ubicación del artículo 1956 del Código Civil.

Sin embargo, a pesar de la claridad de la primera parte del artículo, seguidamente se señala: "(...) para que el destinatario sea acreedor de la prestación es necesario su asentimiento expreso o tácito". Tal expresión nos puede causar cierta perplejidad, pues si en un inicio se señaló que la relación obligatoria se formó con la simple declaración del promitente, entonces ya no debe exigirse ninguna declaración adicional —ni del promitente ni de su destinatario- para que se produzca tal efecto. Sin embargo, luego de analizar con detenimiento ambas expresiones, cualquier duda queda resuelta toda vez que la declaración del destinatario no se exige para el surgimiento de la obligación - pues ésta surgió con la declaración del promitente-, sino, como el propio texto señala, para que el destinatario sea acreedor de la prestación. Adviértase que la norma posibilita separar dos momentos distintos: (a) el nacimiento de la obligación - con la sola emisión de la promesa- y (c) la conversión del destinatario de la promesa en acreedor - con su asentimiento expreso o tácito-.

Aunque parezca que el artículo 1956 del Código Civil tiene cierta influencia de la corriente contractualista -ya que exige la intervención del destinatario de la promesa para que se convierta en acreedor-, consideramos que tal afirmación no es exacta, toda vez que la declaración del acreedor no califica como una aceptación en sentido técnico, por las siguientes razones: (a) pensamos-aunque ello no ha sido manifestado de manera expresa en la Exposición de Motivos del Código Civil-que el legislador peruano quiso respetar el Principio de la intangibilidad de la esfera jurídica individual, y por tanto, consideró necesario el asentimiento previo - expreso o tácito- del destinatario de la promesa antes de convertirlo en acreedor; (b) por el efecto retroactivo que se le ha otorgado al "asentimiento" del destinatario de la promesa, pues si fuese una "aceptación", la obligación surgiría desde que tal aceptación sea conocida por el oferente -artículo 1373 del Código Civil- y no desde la emisión de la promesa -artículo 1956 del Código Civil-.

Asimismo, consideramos que al momento de regular a la promesa unilateral, el legislador tuvo que elegir entre las siguientes tres opciones:

a) Que el derecho otorgado por la promesa ingrese automáticamente a la esfera jurídica del destinatario, convirtiéndolo en acreedor, y sin tener éste la posibilidad de rechazar tal efecto. Así, en caso el destinatario no tenga interés en ejercer el derecho atribuido, simplemente no lo hará, pero nada podrá hacer para impedir la atribución de tal derecho a su esfera jurídica;

b) Que el derecho otorgado en la promesa ingrese automáticamente a la esfera jurídica del destinatario teniendo la posibilidad de rechazarlo retroactivamente, esto es, desde el momento de la emisión de la promesa - como si nunca lo hubiese tenido-; $y$,

c) Que el derecho otorgado en la promesa no ingrese a la esfera jurídica del destinatario sino hasta su asentimiento, el mismo que, de producirse, tendrá efecto retroactivo desde el momento de la emisión de la promesa.

De estas tres opciones, del texto del artículo 1956 del Código Civil se desprende que el legislador peruano acogió la última. Sin embargo, consideramos que dicha elección no es acertada, pues si nuestro legislador optó por recono-

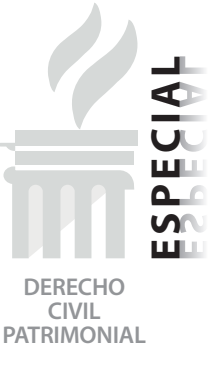

CIVIL
PATRIMONIAL 
cer efectos obligatorios a la promesa unilateral lo razonable hubiese sido que el destinatario de la promesa se convierta en acreedor desde el momento en que la promesa se dirija a su destinatario -o, en el caso de la promesa hecha pública, desde que ésta se haga pública-. En ese sentido -en opinión que compartimosseñala Forno:

“(...) se ha querido admitir la promesa unilateral como fuente de obligaciones, pero el legislador parece no haber podido desprenderse de la bilateralidad para la atribución de los efectos de ella, lo cual implica una seria contradicción (...)."152

Consecuencia práctica de la asunción de la tercera opción descrita, es que al destinatario de la promesa, en caso se prometa transferir la propiedad de un bien inmueble, no le será aplicable los efectos del artículo 949 del Código Civil, según el cual "la sola obligación de enajenar un inmueble determinado hace al acreedor propietario de él (...)", ya que no tendremos "acreedor" hasta que el destinatario de la promesa no haya brindado su asentimiento. Es decir, el destinatario de la promesa no será acreedor - y en consecuencia, no será propietario - hasta que no manifieste su asentimiento. Esta disposición favorece al destinatario de la promesa, ya que de habérsele considerado acreedor desde la emisión de la promesa, éste debería asumir las responsabilidades propias del propietario. En general, el destinatario de la promesa se libera de todas las responsabilidades que tiene un propietario.

Podríamos citar, a guisa de ejemplo, el caso en que a alguien se le atribuya, mediante una promesa unilateral, la propiedad de un edificio, el mismo que, por falta de conservación, se de- rrumbe y cause daño a una persona. Se trata del supuesto contenido en el artículo 1980, que señala: "El dueño de un edificio es responsable del daño que origine su caída, si ésta ha provenido por falta de conservación o de construcción". Sin embargo, por la forma en que se ha regulado a la promesa unilateral, en este supuesto, no es responsable el destinatario de la promesa hasta que no brinde su asentimiento, pues recién en ese momento será acreedor e, inmediatamente, propietario de conformidad a lo dispuesto por el mencionado artículo $949^{53}$.

Finalmente, la última parte del artículo 1956 corrobora que la obligación nació desde la emisión de la promesa, por ello dispone que los efectos del asentimiento del promisario se retrotraen a dicho momento. Sin embargo, el Servicio de Administración Tributaria - SAT- no ha considerado tal efecto retroactivo, pues en el literal d) del artículo 5 de la Directiva № 001-006-00000012, "Establecen lineamientos para la aplicación del Impuesto de Alcabala en el ámbito de la Municipalidad Metropolitana de Lima" de fecha 6 de junio de 2008, señala que la obligación tributaria de pagar el impuesto de alcabala, nace en la oportunidad en que se produce la transferencia que, para el caso de la promesa unilateral, se considera la fecha del consentimiento del destinatario, es decir, como si fuera un contrato.

\section{Supuestos en los que la promesa unilate- ral es obligatoria.}

Bajo el texto del artículo 1956 del Código Civil cualquier declaración unilateral podría ser considerada obligatoria; sin embargo, consideramos que tal disposición sería peligrosa, pues si todas las promesas fuesen obligatorias, nadie prometería nada, o tendrían mucho cuidado

52. FORNO FLÓREZ, Hugo. “El contrato con efectos reales". En: Revista lus et Veritas, No 07, Año IV. Lima: 1993, p. 87.

53. Sin embargo, si interpretamos el artículo 949 del Código Civil, con un criterio lógico e histórico, concluiremos, necesariamente, en que no es la obligación la que transmite la propiedad, sino el contrato. en ese sentido: FORNO FLÓREZ, Hugo. "El contrato con efectos reales". En: Revista lus et Veritas, № 07, Año IV. Lima: 1993, pp. 77-87; ESCOBAR ROZAS, Freddy. "El Contrato y los efectos reales (Análisis del sistema de transferencia de propiedad adoptado por el Código civil peruano)". En: Estudios sobre el contrato en general por los sesenta años del Código civil italiano (1942-2002), Ara. Lima: 2002, pp. 233-256; y FERNÁNDEZ CRUZ, Gastón. "La obligación de enajenar y el sistema de transferencia de la propiedad inmueble en el Perú". En: Themis - Revista de Derecho, № 30. Lima:1994, pp. 149-173, entre otros. 
al momento de realizar una promesa, ya que al ser obligatoria, el destinatario de dicha promesa podría ejercer los remedios legales que corresponden a todo acreedor.

Es por ello que, por regla general, las promesas no son obligatorias, más bien, la excepción es que las sean. Por ello, el artículo 1957 dispone que: "La promesa unilateral sólo obliga a la prestación prometida en los casos previstos por la ley o por acuerdo previo entre las partes interesadas". La norma trascrita restringe el ámbito de promesas unilaterales obligatorias, reduciéndolas a dos supuestos: (a) En los casos previstos por la ley, y (b) Por acuerdo previo de las partes interesadas. Veamos los alcances de ambos supuestos.

\section{Casos previstos por la ley.}

El primer supuesto del artículo 1957 señala que sólo serán obligatorias las promesas previstas por la ley. La pregunta surge de inmediato: ¿cuáles son las promesas reguladas por la ley? Dentro de la Sección Quinta del Libro VII se distinguen cuatro supuestos de promesas unilaterales: (a) la promesa de pago —artículo 1958 - (b) el reconocimiento de deuda —artículo 1958-, (c) la promesa de pública recompensa -artículos 1959 a 1965-, y (d) La promesa de prestación como premio de un concurso - artículos 1966 y 1967-. Adicionalmente a estos supuestos, en la doctrina comparada suelen citarse el caso de los títulos valores, la promesa de fundación, entre otros $^{54}$. En el siguiente numeral describiremos de manera general los alcances de cada especie de promesas unilaterales antes referidas.

En consecuencia, no será obligatoria la promesa unilateral realizada por una persona en la que prometa realizar una prestación a favor de otra, si dicha promesa no se subsume en alguno de los supuestos previstos legalmente. Es decir, si se pretende que tal declaración tenga efectos obligatorios, será necesaria la aceptación de la otra parte, configurándose ya no una promesa unilateral, sino un contrato.

\section{Casos en que existe acuerdo previo entre las partes.}

A diferencia de lo que sucede con su antecedente legislativo -artículo 1987 del Código Civil Italiano-, el artículo 1957 de nuestro Código Civil permite que las partes, previo acuerdo, puedan otorgar efectos obligatorios a sus promesas unilaterales. Es decir, tendrá efectos obligatorios aquella promesa unilateral cuando el promitente y el —eventual- promisario hayan acordado que en caso uno de ellos realice una promesa al otro, esta promesa será obligatoria para el promitente, sin ser necesario para ello que el promisario brinde su asentimiento - pues ya lo hizo justamente en el acuerdo previo-.

En Italia, por el contrario, las promesas unilaterales sólo son obligatorias en los casos previstos por la ley. Así, el artículo 1987 del Código Civil italiano señala que "La promesa unilateral de una prestación no produce efectos obligatorios fuera de los casos admitidos por la ley". Tal situación ha generado críticas por parte de un sector de la doctrina italiana que ha sostenido la inutilidad de tal norma, pues reviste la naturaleza de una simple norma de reenvío. Así, por ejemplo, Graziani señala que "(...) el artículo no afirma que las promesas son típicas, sino que no producen efectos fuera de los casos permitidos por la ley ${ }^{\prime \prime 55}$. Por su parte, Messineo sostiene que esta norma es de orden público ${ }^{56}$.

Finalmente, el reconocido jurista italiano Pietro Trimarchi, señala que fuera de los casos previs-

54. Para un estudio detallado sobre distintos supuestos que podrían constituir promesas unilaterales, recomendamos la lectura de GRAZIANI, Op. Cit., pp. 642-654.

55. GRAZIANI, Op. Cit., p. 664.

56. MESSINEO, Francesco. Manual de Derecho Civil y Comercial. Tomo VI, Relaciones Obligatorias Singulares. Buenos Aires: EJEA, p. 216. 
tos por la ley "(...) la promesa de una prestación es vinculante sólo si se inserta en el contexto de un contrato: es necesario, en otras palabras, el consenso, expreso o tácito, del promisario"157. Esta idea se encuentra reflejada en nuestro artículo 1957 in fine.

\section{5. ¿Cuándo una declaración unilateral cons- tituye una promesa unilateral?}

Como hemos referido en los dos numerales precedentes, para que una declaración unilateral sea considerada como una promesa unilateral - y tenga sus efectos-, es necesario que esté prevista legalmente o que las partes previamente hayan acordado otorgar tal carácter a sus declaraciones unilaterales.

No obstante, lo expuesto, cierto sector de la jurisprudencia nacional parece considerar a toda declaración unilateral como una promesa unilateral. En efecto, en la Sentencia de Casación 347-98-LIMA del 4 de julio del 2000, expedida por la Sala Transitoria de Derecho Constitucional y Social de la Corte Suprema de Justicia de la República, en el proceso judicial seguido por el Sr. César Augusto Castamán Risco con Telefónica del Perú S.A. —en adelante, "TdP"—, sobre pago de remuneraciones insolutas, la Sala Suprema ha declarado fundado el recurso de casación interpuesto por el Sr. Castamán considerando que el Acta de Compromiso emitido por TdP el 1 de junio de 1996 constituye una promesa unilateral que obliga a TdP. Asimismo, la Sala Suprema señala que otras Salas Laborales, en base a lo dispuesto en el artículo 1956 del Código Civil, reconocen al "Acta de Compromiso" naturaleza de promesa unilateral. Así, en la citada sentencia, la Sala señala lo siguiente:

"(...) la figura de la promesa unilateral es de naturaleza distinta a la de un convenio colectivo, en donde concurre la voluntad de los trabajadores, representados por un sindicato, y la del empleador y/o empleadores, con la finalidad de solucionar discrepancias de índole laboral. Sexto: Que, siendo esto así, resulta claro que la naturaleza del documento denominado acta de compromiso del primero de junio de mil novecientos noventiséis, es una declaración o promesa unilateral que obliga a Telefónica del Sociedad Anónima, más aún, si dicho documento carece de los requisitos propios de un Convenio Colectivo de Trabajo a que se refiere el artículo cuarentitrés de la Ley número veinticinco mil quinientos noventitrés, que dispone, entre otros presupuestos, su formalización por escrito en tres ejemplares ante la Autoridad Administrativa de Trabajo para su respectivo archivo y registro. Séptimo: Que, en consecuencia, la Sala de mérito al concluir y otorgar a la referida Acta de Compromiso, el carácter de Convenio Colectivo, lo ha hecho en evidente violación del citado artículo mil novecientos cincuentiséis del Código Civil, contradiciendo además el pronunciamiento de otras Salas Laborales que, en base a dicha norma, le reconocen naturaleza de promesa unilateral (..) $)^{\prime \prime}$ el subrayado es nuestro-.

Como se puede apreciar de la sentencia transcrita, la Sala Suprema, en primer lugar, considera que el Acta de Compromiso emitido por TdP no tiene la naturaleza de un Convenio Colectivo, e inmediatamente concluye en que su naturaleza es la de una promesa unilateral, sin realizar el más mínimo análisis para arribar a tal conclusión - ! - Como señalamos cuando tuvimos la oportunidad de comentar esta sentencia ${ }^{58}$, para verificar si una declaración unilateral —en este caso, el Acta de Compromiso emitido por $\mathrm{TdP}$ - constituye una promesa unilateral, basta simplemente apreciar si la misma está comprendida dentro de los supuestos de promesas unilaterales que regula la ley o si existe un acuerdo

57. TRIMARCHI, Pietro. Istituzioni di Diritto Privato. Quinta Edición. Milán: Giuffrè, 1981, p. 295.

58. Huanco Piscoche, Henry. "iMucho cuidado: no toda declaración unilateral es una promesa unilateral!". Comentario jurisprudencial publicado en: Revista Actualidad Jurídica T. 174. Lima: 2008, pp. 74-78.

59. Artículo 1957 del Código Civil: "La promesa unilateral sólo obliga a la prestación prometida en los casos previstos por la ley o por acuerdo previo entre las partes interesadas". 
previo, tal como lo indica el artículo $1957^{59}$. En nuestra opinión, sólo son promesas unilaterales obligatorias la promesa de pública recompensa, la promesa como premio de un concurso, la promesa de fundación y el pagaré. Las razones por las que no consideramos a la promesa de pago y al reconocimiento de deuda como promesas unilaterales las hemos explicado en otra sede ${ }^{60}$.

Ahora bien, como quiera que el Acta de Compromiso emitido por TdP no se subsume dentro de ninguno de dichos supuestos, consideramos que su contenido no constituye una promesa unilateral obligatoria, salvo claro está, si el Sr. Castamán y TdP hayan otorgado previamente tal efecto a dicha declaración, conforme lo permite el artículo 1957 in fine. En consecuencia, consideramos que la Sala Transitoria de Derecho Constitucional y Social de la Corte Suprema, en la sentencia bajo comentario, ha considerado de manera errada al Acta de Compromiso emitida por TdP como una promesa unilateral. Por ello se debe tener mucho cuidado, pues no toda declaración unilateral es una promesa unilateral.

\section{La promesa de pública recompensa y la promesa como premio de un concurso.}

La promesa de pública recompensa, es sin duda la expresión más representativa de las promesas unilaterales. Por la promesa al público el promitente se obliga mediante su declaración hecha en un anuncio público a cumplir una prestación a favor de quien se encuentre en una determinada situación o realice un determinado acto artículo 1959 del Código Civil-. A diferencia de los supuestos anteriores, en los que existe - o se presume la existencia - de una relación causal entre promitente y promisario, que es justamente la que motiva la emisión de la promesa, en la promesa de pública recompensa no existe tal relación previa entre las partes; la vinculación más bien se presentará recién desde que la persona quien tomó conocimiento del anuncio público avisa al promitente que ejecutó el acto por él requerido y exige la recompensa.
Otra diferencia con la promesa de pago y el reconocimiento de deuda es que en éstos, el destinatario de estas declaraciones está legitimado para ser acreedor; mientras que en la promesa de pública recompensa estará legitimado para ser acreedora cualquier persona que se encuentre en la situación determinada o haya ejecutado el acto indicado en el anuncio público.

De otro lado, tenemos a una especie de la promesa de pública recompensa que comúnmente se le denomina "promesa como premio de un concurso". Este supuesto se distingue de la promesa pública strictu sensu en que: (a) por lo general, no está dirigida a todo el público, sino sólo a los participantes del concurso y, (b) además, para obtener el premio no será suficiente realizar algún acto o encontrarse en la situación establecida en la promesa - como sucede en la promesa de pública recompensa-, sino que los concursantes deberán comportarse de manera diligente y con preparación técnica y profesional, dependiendo de las características del concurso, siendo necesario también que el jurado tome la decisión de otorgar el premio.

\section{LA RESPONSABILIDAD CIVIL EN LA PRO- MESA UNILATERAL}

\section{Consideraciones generales.}

Una vez que se haya generado una obligación derivada de una promesa unilateral, su incumplimiento se regirá bajo las normas que regulan la inejecución de obligaciones —artículos 1314 a 1350, en lo que sean aplicables-. Sin embargo, dentro de las normas que regulan la promesa de pública recompensa, existen normas específicas referidas a la posibilidad de revocar la promesa e indemnizar los daños que tal revocación podría generar a los promisarios.

Así, el artículo 1963 del Código Civil regula la revocación de la promesa pública en los términos siguientes:

60. HUANCO PISCOCHE, Henry. "La Cenicienta del Derecho Civil: La Promesa de pago y el Reconocimiento de deuda". En: ADVOCATUS N 17 . Lima: 2008, pp. 233-250. 
"Toda promesa al público puede ser revocada por el promitente en cualquier momento. Empero si fuese con plazo de validez determinado, sólo por justo motivo podrá ser revocada por el promitente dentro del indicado plazo, con cargo a indemnizar los daños y perjuicios que la revocación ha causado a quienes justificadamente depositaron su confianza en la vigencia de la promesa".

Como se puede apreciar, la norma otorga efectos distintos a la revocación de la promesa pública, según ésta tenga o no un plazo de validez determinado. En atención a ello, a continuación analizaremos cada uno de estos supuestos.

\subsection{Si la promesa no tiene plazo de validez determinado.}

En caso el promitente no establezca un plazo dentro del cual su promesa será eficaz, se aplica la regla contenida en la norma trascrita, es decir, la promesa podrá ser revocada por el promitente en cualquier momento. Sin embargo, el término "cualquier momento" debe ser interpretado como cualquier momento antes de que el promisario, habiendo cumplido el acto requerido por el promitente, haya comunicado tal cumplimiento al promitente, pues en ese momento ya se habría individualizado al acreedor de la relación obligatoria, no pudiendo el deudor - promisario- dejar sin efectos la obligación a su cargo por su sola voluntad, debiendo cumplir su obligación de entregar la recompensa. La imposibilidad de que el deudor, unilateralmente, pueda dejar sin efectos la obligación a su cargo se presenta en toda clase de obligación, con independencia de la fuente de la que emane.

En el mismo sentido, señala Sbisá, "en ningún caso, la revocación puede tener efecto si la situación prevista en la promesa ya se ha verificado o si la acción ya ha sido completada"61.
Interpretando sistemáticamente el artículo 1963 con el 1962 por "plazo de validez — rectius: vigencia- determinado", se debe entender aquel plazo necesariamente impuesto por el promitente - sea expreso o tácito-, mas no el plazo supletorio de 1 año que establece el artículo 1962. Entonces, si la promesa no tiene plazo de validez determinado, el promitente tiene la plena libertad de revocar su promesa cuando lo crea conveniente - antes de que le hayan comunicado la verificación del acto por él solicitado-, no asumiendo responsabilidad alguna por los daños que dicha revocación pudiera ocasionar a los promisarios.

Como se señala en la Exposición de Motivos del Código Civil,

“(...) la revocación de la promesa, en el caso del primer párrafo del artículo 1962, no genera responsabilidad del promitente por los gastos que hayan realizado las personas interesadas en adquirir derechos a la prestación prometida"62.

Esta disposición es razonable, pues el promisario - eventual perjudicado con la revocaciónsabe que dicha promesa no tiene un plazo fijo, lo que atenúa la solidez de la promesa. Así, cuando el promisario toma conocimiento de la promesa - ve el anuncio público-y éste no tiene un plazo determinado, es razonable que sospeche que la misma ya no sea eficaz, por haber sido cumplida por otra persona, por lo que un promisario diligente se comunicaría con el promitente para confirmar la vigencia de la promesa y recién luego de confirmar que la promesa está vigente, iniciaría los actos necesarios para cumplir el acto requerido en el anuncio público. De lo contrario, si el promisario, sin informarse previamente sobre la vigencia de la promesa, inicia tales actos y, en el camino, el promitente revoca su promesa -inclusive sin

61. SBISÁ, Giuseppe. La Promessa al Pubblico. Milán: Giuffré, 1974, p. 265.

62. Exposición de Motivos y Comentarios del Código Civil, Tomo VI, Comisión encargada del estudio y revisión del Código Civil, compiladora Delia Revoredo De Debakey, Lima, 1985, pp. 792-793. 
"justo motivo"-, éste no tendrá obligación alguna de reembolsar los costos que aquel incurrió hasta la fecha.

\subsection{Si la promesa tiene plazo de validez de- terminado.}

El segundo supuesto del artículo 1963 se presenta cuando la revocación se realiza dentro del plazo de vigencia de la promesa - expreso o tácito-, pues luego de dicho plazo, la promesa ya no será eficaz - y no habrá nada que revocar-. Como en el caso anterior, la revocación puede realizarse siempre antes de que se haya cumplido el acto solicitado en el anuncio público, pues en dicho momento ya se habrá individualizado al acreedor, y el deudor no puede dejar sin efectos una obligación a su cargo por su sola voluntad.

Según la norma bajo análisis, el promitente sólo podrá revocar su promesa por justo motivo, contrario sensu, no podrá hacerlo -o si lo pretende hacer, ésta será ineficaz-, y en el eventual caso que el promisario cumpla el acto requerido en el anuncio público, el promitente estará obligado a entregarle la recompensa.

Téngase en cuenta que por más que la revocación sea realizada por justo motivo, el promitente estará obligado a indemnizar los daños que su revocación haya generado a las personas que, confiando en la vigencia de la promesa, comenzaron a realizar las acciones necesarias para cumplir el acto solicitado por el promitente en su anuncio público. Los daños que deberán ser indemnizados son todos aquéllos que tengan relación directa con la ejecución del acto requerido por el promitente. Así, por ejemplo, la reparación del daño emergente cubriría todos los gastos efectivos que haya realizado el promisario para ejecutar el acto indicado en el anuncio público.

Al respecto, Martinez de Aguirre y Aldaz $^{63}$ señala que el lucro cesante sólo
"(...) correspondería a aquel que probara efectivamente que él hubiera sido el beneficiario de la recompensa (...). Si la indemnización se otorgara a cuantos han realizado gastos en vista de la recompensa, es fácil deducir que el promitente se vería obligado a entregar en tal concepto una suma superior a la recompensa, lo que vendría a colocarle en peor condición que si no hubiera revocado. $Y$ si se limita el total de las indemnizaciones a la cuantía de la recompensa (...), cada uno de los derechohabientes a esa indemnización podría encontrarse con una suma muy reducida que, en absoluto, compensase los gastos por él realizados o los perjuicios sufridos por él $-y$, por lo tanto, no puede considerarse propiamente como indemnización (...)".

Por tales razones, en opinión del autor español, la imposición de la obligación de indemnizar no es del todo satisfactoria para el promitente ni para los destinatarios, y puede ser fuente casi inagotable de procedimientos judiciales, por lo que propone rechazar la regulación de la revocabilidad de la promesa.

Adviértase la consecuencia establecida por la norma contenida en el artículo 1963: el promitente sólo por justo motivo podrá revocar su promesa dentro del plazo de eficacia y, aun en tal caso, estará obligado a indemnizar por los daños que su promesa ha causado a las personas que confiaron en la validez de dicha promesa. Esto es importante porque nos permite descartar la tesis expuesta por Giorgianni, quien niega la existencia de una relación obligatoria al momento de que la promesa se hace pública, afirmando más bien que tal relación obligatoria recién surge con la individualización del acreedor - que se produce recién con el cumplimiento del acto o la verificación de la situación indicada en la promesa-. Para sustentar su tesis, Giorgianni se basa en la facultad que el ordenamiento jurídico otorga al promitente de revocar su promesa en cualquier momento antes de que el acreedor sea individualizado. 
Para efectos de comprender claramente la tesis del profesor italiano, a continuación citaremos su idea textualmente:

"Respecto de la promesa al público prevista por el artículo 1989 CC [del Código civil italiano], creemos es posible demostrar que en virtud de la promesa no surge en absoluto una relación obligatoria entre el promitente y una persona indeterminada, sino que, por el contrario, la relación obligatoria surge sólo en el momento en que la persona del acreedor viene a ser individualizada. En otros términos, el hecho de que sea determinada actualmente la persona del deudor, mientras respecto al acreedor existen solamente los criterios para su futura individualización, no es suficiente para llegar a la conclusión de que la relación obligatoria existe actualmente entre una persona cierta y otra incierta (...). La ley —artículo 1990 pr.- permite al promitente revocar la promesa, lo que demuestra que un derecho de crédito, aunque sea a favor de persona indeterminada, no existe todavía. Si tal derecho debiera considerarse existente, sería en efecto, contrario al principio de que pudiera desaparecer por medio de la voluntad del sólo obligado; y, en efecto, la ley declara ineficaz la revocación si la situación prevista se ha verificado ya o si la acción ha sido ya realizada" ${ }^{\prime \prime 4}$ —el subrayado es nuestro-.

Como se puede apreciar, el fundamento de la tesis de Giorgianni se basa en la posibilidad que tiene el promitente de revocar su promesa. Al respecto, debemos señalar que el promitente no tiene la plena facultad de revocar su promesa. Como hemos subrayado supra, sólo podrá revocar su promesa por justa causa. Es más, aun si su revocación se hubiere realizado por justa causa, no estará libre de indemnizar los daños que su revocación haya causado a las personas que, confiando en su validez, hayan comenzado a ejecutar el acto requerido en el anuncio público.

Finalmente, debemos señalar que si al promitente se le otorga la facultad de revocar su promesa es porque con este acto no se está afectando a nadie en particular - pues a diferencia del contrato, no existe un acreedor determinado-, sin embargo, reiteramos, en caso alguien se vea perjudicado con esta revocación, el promitente estará obligado a indemnizar los daños que tal revocación hubiere generado. Por ello, no es cierto, como señala Giorgianni, que el deudor, mediante la revocación, tiene la plena libertad de dejar sin efecto su obligación por su sola voluntad.

\subsection{Momento de la revocación y "justo motivo".}

En otros países se prohíbe revocar la promesa después de que el promitente haya comenzado a realizar el acto previsto en el anuncio público. Ello sucede con los Códigos de Túnez - artículo 20- y Marruecos - artículo 17-. No compartimos tal posición, toda vez que ello perjudica al promitente al estar impedido de revocar su promesa, no obstante que nadie hubiere cumplido el acto por él requerido.

Consideramos, más bien, que lo razonable es prohibir la revocación cuando ya se ha ejecutado la prestación por completo. Así, el Código alemán, seguido por el brasileño y también por el suizo permiten la revocación de la promesa antes de la ejecución del acto, porque consideran que el promitente se ha obligado bajo la condición de que se llegue a ejecutar el acto, de modo que hasta entonces el vínculo obligacional no se perfecciona; en otros términos, la promesa aún le pertenece al promitente $y$, por lo tanto, puede retirarla ${ }^{65}$.

64. GIORGIANNI, Michele. La Obligación (La parte general de las obligaciones). Traducción de la edición italiana de Evelio Verdera y Tuells. Barcelona: BOSCH, 1958, pp. 49-50.

65. LEÓN BARANDIARÁN, José. Tratado de Derecho Civil peruano. Tomo IV (Teoría General del Contrato, Voluntad Unilateral y Responsabilidad Extracontractual). Lima: Walter Gutiérrez Editor, 1992, p. 297. 
De otro lado, no bastará la simple justificación de la revocación para que el promitente quede exento de cumplir la recompensa ofrecida. Es necesario que ésta haya sido realizada por un justo motivo, pero ¿qué debemos entender por "justo motivo"? Para D'amelio, "(...) la justa causa puede ser el sobrevenir de un hecho que vuelve inútil la prestación requerida o la prohibición de la autoridad (...). Esa debe ser apreciada por el Juez caso por caso" ${ }^{116}$.

Por su parte, Di Majo señala que "(...) la justa causa de revocar debe referirse a hechos o eventos caracterizados por objetividad y no por una diversa estimación del interés del promitente ${ }^{1 / 67}$. Como ejemplos se han señalado:

“(...) organización de una feria de muestras con premio, en el caso de que la autoridad administrativa impida su celebración (aunque si la feria no tiene lugar, decae la promesa sin necesidad de revocación), sobreveniencia de hijos del promitente, o de algún hecho que haga inútil la prestación (...)"168.

Para Sbisá, "(...) justa causa de revocación sería cualquier hecho que, según la disciplina general del contrato, aplicable en cuanto sea compatible a cada acto entre vivos de contenido patrimonial (artículo 1324 del código civil italiano), legitima la impugnación del negocio"69.

Finalmente para $\mathrm{Ferri}^{70}$, subsiste la justa causa de revocación cuando "(...) el fenómeno de cooperación económica (...) por hecho independiente de la voluntad del promitente, se presenta como irrealizable", proponiendo las siguientes dos hipótesis donde esta situación se verificaría: (a) aquélla en la que la prestación prometida deviene en imposible por hecho independiente de la voluntad del promitente, y (b) aquélla en la que deviene en imposible la realización de aquél interés del promitente en función de la cual la promesa fue dada.

Efectivamente, dejar al arbitrio del promitente la determinación de la "justa causa" sería perjudicial para los intereses de los promisarios, pues en tal escenario, el promitente podría incumplir la obligación de entregar la recompensa - por más que tenga la obligación de indemnizarbajo el pretexto de que revocó su promesa por una justa causa. A nuestro parecer, se debe entender por "justo motivo" o "justa causa" algún acontecimiento ajeno a la voluntad del promitente, como son el caso fortuito, la fuerza mayor o el hecho de un tercero que afecten la causa o la razón que motivó al promitente efectuar la promesa y provocan la invalidez o ineficacia de la promesa. Sólo en esos casos debidamente acreditados, el promitente estaría facultado para revocar su promesa, siempre que tal revocación: (a) se produzca antes de que el promisario haya cumplido el acto requerido en el anuncio público; y (b) haya sido publicitada por el mismo medio que se utilizó para realizar la promesa, conforme lo dispone el artículo 1964 del Código Civil.

66. D`AMELIO, Mariano y FINZI, Enrico. Codice Civile, Libro delle obbligazioni. Vol. III, G. Florencia: Barbèra Editore, 1949, p. 11.

67. DI MAJO. Op. Cit., p. 124.

68. En ese sentido: BRANCA, Promesse unilaterali; Falqui-Masidda, Promessa unilaterale y SBISÁ, La promessa al pubblico, cit. por MARTÍNEZ DE AGUIRRE, Op. Cit., pp. 83-84.

69. SBISÁ. Op. Cit., p. 267.

70. FERRI, G. Le Promesse unilaterali Cit. por Sbisá, Op. Cit., pp. 272-273. Asimismo, Ferri señala que la hipótesis en la que se prometa una suma a favor de quien invente un determinado procedimiento industrial, y después se descubre que el procedimiento ya ha sido inventado por una determinada persona puede ser revocado por justa causa. Sin embargo, coincidimos con Sbisá en que en este caso, en lugar de revocar por justa causa, más bien se trataría de un caso de nulidad por imposibilidad del objeto. 


\subsection{Indemnización a quienes confiaron en la vigencia de la promesa.}

Por más que el promitente haya efectuado la revocación por justo motivo, estará obligado a indemnizar los daños que hubiere causado a las personas que estaban ejecutando el acto establecido en el anuncio público. La fuente de la obligación de indemnizar es la ley.

Siendo consecuentes con nuestra posición de considerar a la promesa unilateral como fuente de obligaciones, como también lo ha hecho el legislador peruano, no podemos sustentar esta responsabilidad en la denominada "responsabilidad precontractual" o "culpa in contrahendo", como pretende un sector de la doctrina ${ }^{71}$, pues no estamos en una etapa anterior a un contrato. Sin embargo, para definir el quantum indemnizatorio sí podemos utilizar un concepto propio de la responsabilidad precontractual, nos referimos al interés negativo.

Según Asúa, la reparación del interés negativo:

“(...) pretende reponer, en términos económicos, las cosas al estado en que estarían si el perjudicado nunca hubiera oído hablar del contrato o no hubiera confiado en su validez, por ello también se le denomina interés de confianza."72

Aplicando este concepto a la promesa unilateral tendríamos que la indemnización del interés negativo pretende reponer, en términos económicos, las cosas al estado en que estarían si el promisario nunca hubiera oído hablar de la promesa o no hubiera confiado en su validez.
Esta indemnización constituye una expresión más del deber de buena fe, pues se busca reparar los daños ocasionados a la persona, quien, de buena fe, había confiado en la promesa y que, por ello, comenzó a realizar los actos encaminados a realizar el acto requerido por el promitente.

Sin embargo, Ramírez ha considerado que lo correcto sería que se indemnicen a todos aquellos que sin importar si tuvieron confianza o no en la promesa, pero basados en la publicidad de la misma, hayan sufrido algún daño por la frustración que implica la revocación de dicha promesa, pues pudiera haber principio de ejecución ${ }^{73}$. No compartimos tal opinión, pues, como hemos dicho, la norma bajo comentario encuentra sustento en la buena fe, por lo que en caso el promitente haya comenzado a ejecutar la prestación sin confiar en la promesa, no tendría sustento su solicitud de reparación.

\subsection{Daños sufridos por el promisario mayo- res al monto de la recompensa.}

Como señala Sbisá74, si el quantum indemnizatorio equivaliera al valor de la recompensa, la revocación no tendría ninguna utilidad para el promitente, pues debería entregar la suma prometida en recompensa, de la misma forma que no hubiera habido revocación. Sin embargo, ¿qué sucedería si los daños sufridos por una persona que inició los actos para cumplir el acto requerido por el promitente, confiando en la seriedad del aviso, son mayores a la recompensa?, ¿estaría el promitente obligado a indemnizar el monto total del daño?

Al respecto, el artículo 1139 del Código ve-

71. Así señala, entre otros: DE COSSíO, Alfonso. Instituciones de Derecho Civil. Tomo I, Parte General. Derecho de Obligaciones. Madrid: Alianza Editorial, 1977, p. 243.

72. ASÚA GONZÁLEZ, Clara. La Culpa in Contrahendo (Tratamiento en el Derecho alemán y presencia en otros ordenamientos). Bilbao: Departamento de Publicaciones de la Universidad del País Vasco, 1989, pp. 67-68.

73. RAMíREZ, Nelson. Apuntes Contractuales. En: Biblioteca Jurídica Contemporánea No. 07. Lima: San Marcos, 2004, p. 74.

74. SBISÁ. Op. Cit., p. 267. 
nezolano de 1942 establece que el autor de la revocación está obligado a rembolsar los gastos hechos por aquéllos que, de buena fe y antes de la publicación de la revocación, han comenzado a ejecutar la prestación, pero sin que la suma total a rembolsar pueda exceder el monto de la recompensa prometida. Esta posición es compartida por D'Amelio, quien señala que "(...) el resarcimiento es limitado al reembolso de los gastos y que éstos, en cada caso, no deben superar el importe de la remuneración prometida (... $)^{\prime \prime 75}$.

No compartimos la solución ofrecida por el referido código ni por el autor citado, toda vez que la indemnización, en este caso, encuentra sustento en la buena fe, no teniendo relación con el monto de la recompensa. En atención a ello, dicho monto no tiene que servir como límite para fijar el quantum indemnizatorio; además, no existe norma legal alguna que establezca tal limitación de responsabilidad. En consecuencia, el promitente estaría obligado a reparar íntegramente el daño causado, aun si el monto de éste fuese mayor a la recompensa prometida.

\subsection{Invalidez de la revocación.}

Habíamos dicho que la regla establecida en el artículo 1963 consiste en que la promesa puede ser revocada en cualquier momento, siempre que sea realizada antes de que el promisario haya cumplido el acto solicitado por el promitente. Esta regla se aplica para las promesas sin plazo de validez determinado e, inclusive, para las promesas con plazo de validez determinado. En este último caso, la revocación será válida si se efectúa dentro del plazo de vigencia contemplado en la promesa - expresa o tácitamente-, siempre que la revocación haya obedecido a un justo motivo. No obstante que se le permite al promitente revocar su promesa, no se le libera de indemnizar los daños que haya causado a las personas que, confiando en su promesa, venían rea- lizando actos encaminados a lograr la acción por él requerida.

Ahora bien, la regla descrita en el párrafo anterior encuentra su excepción en dos supuestos en los que la revocación no será válida y, por lo tanto, el promitente estará obligado a entregar la recompensa ofrecida en la promesa. Estos supuestos se presentan: (a) si la revocación no se ha hecho pública de la misma forma en que se hizo la promesa, y (b) si la revocación se ha hecho luego de haberse verificado la situación prevista en la promesa o de haberse ejecutado el acto solicitado por el promitente.

En el primer supuesto se pretende tutelar a los terceros que han tomado conocimiento de la promesa y estén asumiendo una serie de costos para cumplir el acto requerido por el promitente y ser acreedores de la recompensa. Así, quienes hayan tomado conocimiento de la promesa por un determinado medio, tomarán conocimiento por el mismo medio, uno equivalente - o uno mejor, en términos de difusiónde que la promesa ha sido revocada. Consideramos que esta carga exigida al promitente es correcta, pues si ésta no estuviera prevista, muchas personas que hubieran realizado el acto indicado en el anuncio público no podrían exigir la recompensa, pues el promitente se negaría a entregar dicha recompensa indicando que la promesa ya había sido revocada, lo cual es una situación injusta.

De igual modo se prohíbe al promitente revocar su promesa si una persona se encuentra en la situación descrita en la promesa o si alguien hubiere ejecutado el acto requerido por el promitente. Así, Medicus señala que:

“(...) en la pública promesa el ejecutante, en cierto modo, debe anticipar la acción. Por ello existe el riesgo de que el promitente quiera eludir su deber de prestación después de estar satisfecho su interés. Para evitar tal situación se limita la revocación de la pública 
promesa; en particular, ésta no puede tener lugar ya después de realizada la acción"76.

\subsection{Renuncia al derecho de revocación.}

Finalmente, el artículo 1965 del Código Civil permite al promitente renunciar al derecho de revocar su promesa. Como quiera que se trata de un derecho de orden privado, es perfectamente renunciable ${ }^{77}$.

La renuncia al derecho de revocar la promesa debe constar en el anuncio público. Una vez que el promitente renuncia a su derecho de revocar su promesa no podrá revocarla durante el plazo establecido en la promesa - expreso o tácito- o del supletorio - 1 año- - Si se ha renunciado anticipadamente al derecho de revocar la promesa y el promitente quiere revocarla cuando ésta se encuentra todavía vigente, tal revocación no tendrá efectos.

La renuncia al derecho de revocación beneficia a los destinatarios de la promesa, pues tienen la certeza de que la promesa no podrá ser revocada hasta que venza su plazo de vigencia. Una promesa con renuncia del derecho de revocación es más atractiva para los destinatarios, pues genera incentivos en lograr el acto indicado en la promesa, por no tener la incertidumbre de que el promitente pueda dejar sin efecto su promesa en algún momento.

76. MEDICUS, Dieter. Tratado de las relaciones obligatorias. Vol. I. Barcelona: BOSCH, 1995, p. 588.

77. LEÓN BARANDIARÁN. Op. Cit., p. 298. 